\title{
An Archaeological Survey of Portions of Mud and St. Joseph Islands Aransas County, Texas
}

Thomas C. Kelly

Follow this and additional works at: https://scholarworks.sfasu.edu/ita

Part of the American Material Culture Commons, Archaeological Anthropology Commons, Environmental Studies Commons, Other American Studies Commons, Other Arts and Humanities Commons, Other History of Art, Architecture, and Archaeology Commons, and the United States History Commons

Tell us how this article helped you.

This Article is brought to you for free and open access by the Center for Regional Heritage Research at SFA ScholarWorks. It has been accepted for inclusion in Index of Texas Archaeology: Open Access Gray Literature from the Lone Star State by an authorized editor of SFA ScholarWorks. For more information, please contact cdsscholarworks@sfasu.edu. 


\section{An Archaeological Survey of Portions of Mud and St. Joseph Islands Aransas}

County, Texas

\section{Creative Commons License}

\section{(c) (1) \&}

This work is licensed under a Creative Commons Attribution-NonCommercial 4.0 International License 


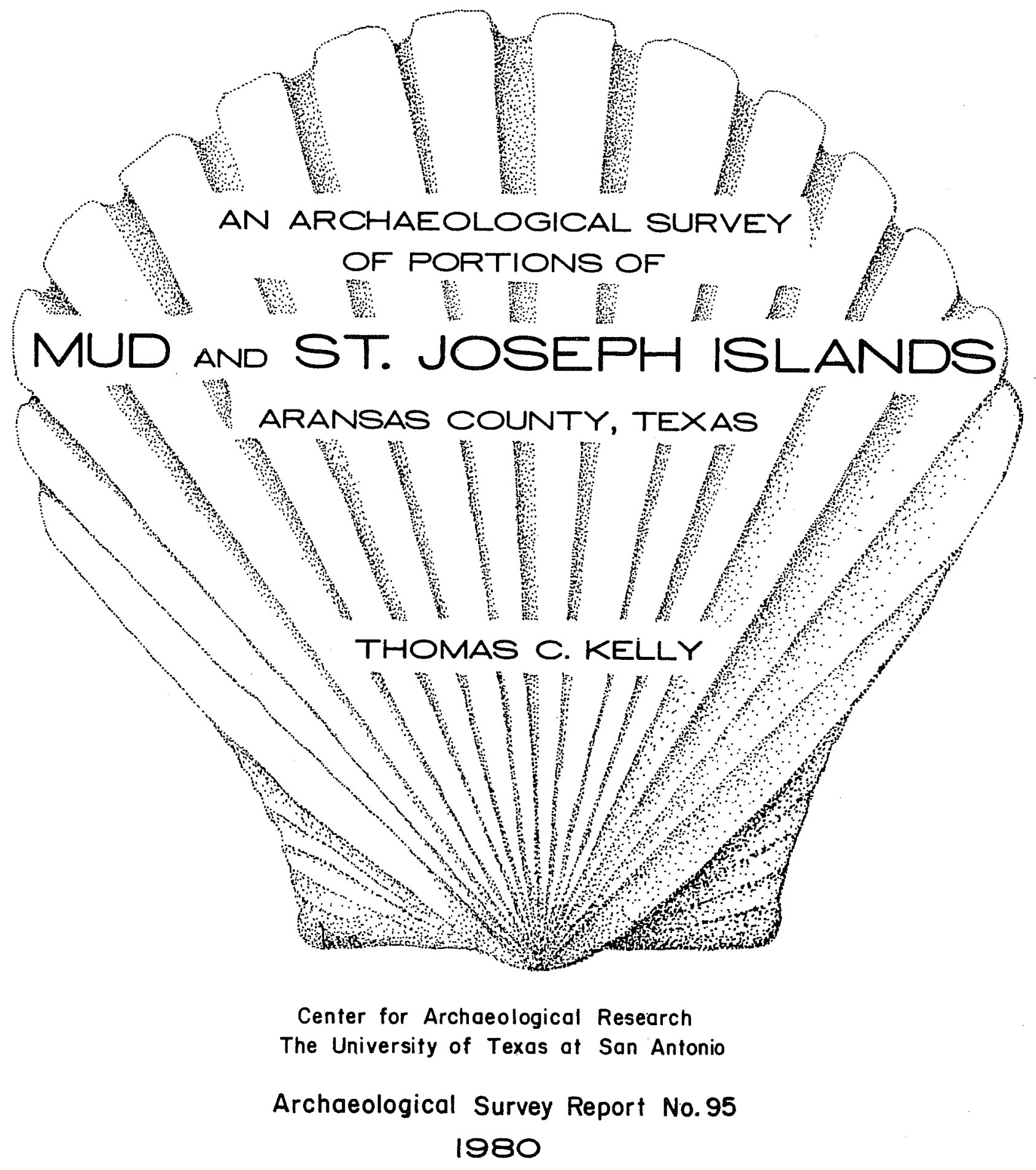




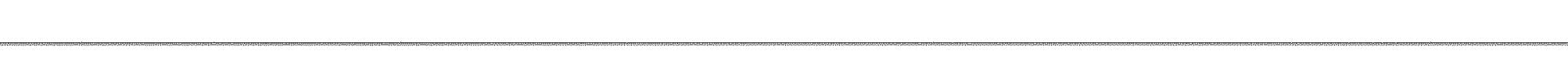


AN ARCHAEOLOGICAL SURVEY OF PORTIONS OF MUD AND

ST. JOSEPH ISLANDS, ARANSAS COUNTY, TEXAS

Thomas C. Kelly

Center for Archaeological Research The University of Texas at San Antonio Archaeological Survey Report, No. 95

1980 
Cover design

by

Kathy Bareiss 
List of Figures. .................. . . . Introduction . . . . . . . . . . . . . . . . 1 The Geographical and Archaeological Region ............ 1 Previous Archaeology of the Area . . . . . . . . . . . . 3 Mud Island Survey. . . . . . . . . . . . . . . . . 4 St. Joseph Island Survey . . . . . . . . . . . . . . . 5 References Cited................... 6

\section{LIST OF FIGURES}

Figure

1. Mud Island/St. Joseph Island Survey Area. . . . . . . . . . . . 2 


\section{INTRODUCTION}

Pursuant to a contract between Channel Industries Gas, a Tenneco subsidiary, and the Center for Archaeological Research (CAR), The University of Texas at San Antonio (letter of June 2 from Stephen E. Kennedy, Channel Industries Gas, to Jack D. Eaton, CAR), an archaeological field survey was made of the proposed natural gas pipeline right-of-way across Mud Island and St. Joseph Island, Aransas County, Texas, on June 9 and 10, 1980.

The survey crew consisted of Thomas C. Kelly and Erwin Roemer of the CAR, James Stavinoha of Channel Industries Gas, and Jerry Crutcher, as helicopter pilot. Overall supervision of the project was provided by Jack D. Eaton, Acting Director of the Center.

\section{THE GEOGRAPHICAL AND ARCHAEOLOGICAL REGION}

St. Joseph Island (San Jose Island) is one of a series of Texas coastal barrier islands formed by subsidence and wave action in the Late Holocene, ca. 6000 B.P. (Gagliano 1977:Plate 1; Valastro, Davis and Varela 1978:245). The island is southeast of Rockport, across Aransas Bay, and 1ies wholly in Aransas County, with its northern tip separated from Matagorda Island, Calhoun County, and its southern tip separated by Aransas Pass from Mustang Island, Nueces County (see Fig. 1). It is approximately 30 miles long and one mile wide; some of the Gulf of Mexico beach dunes rise to a maximum of 35 feet above the beaches. The interior is flat and covered by dense low grass and marsh vegetation. There are only scattered dunes on the Aransas Bay shoreline, where the land stops abruptly without beaches. There are no natural freshwater sources visible, although it may be that heavy rains would produce standing water for short periods of time in the sandy soil. However, the maximum and minimum historical rainfall amounts for Aransas County are 33 and 19 inches, respectively (Texas Almanac 1966-67), so that even potable brackish water would be available only seasonably. Cattle raising is presently the only utilization of the land.

Archaeologically speaking, St. Joseph Island should be the area least disturbed in the region by modern mans' exploitation. Such destruction has been noted in the area by every archaeologist who has worked in the Texas Coastal zone (i.e., Martin and Potter n.d.; Campbel1 1958a; Hester 1975; Patterson 1980). The island is privately owned, has no.roads, bears so far only minimal oil industry activity, has no real estate development except the owners' resort homs and airfield, and is the least accessible of any of the barrier islands.

Mud Island parallels the southern end of St. Joseph Island on the Aransas Bay side, and is separated from it by Blind Pass, a shallow natural pass that has a narrow dredged channel to permit passage of $0 i 1$ company work boats to $0 i 1$ we $11 \mathrm{~s}$ in the bay. Mud Island is approximately three miles long, one-quarter mile wide, and rises only two to three feet above the bay tidal level. It is a shell reef with only sparse marsh grass vegetation, and has no protection from abnormal tides or hurricanes. The survival of fragile aboriginal traces through centuries of hurricanes and high tides is rather doubtful. 


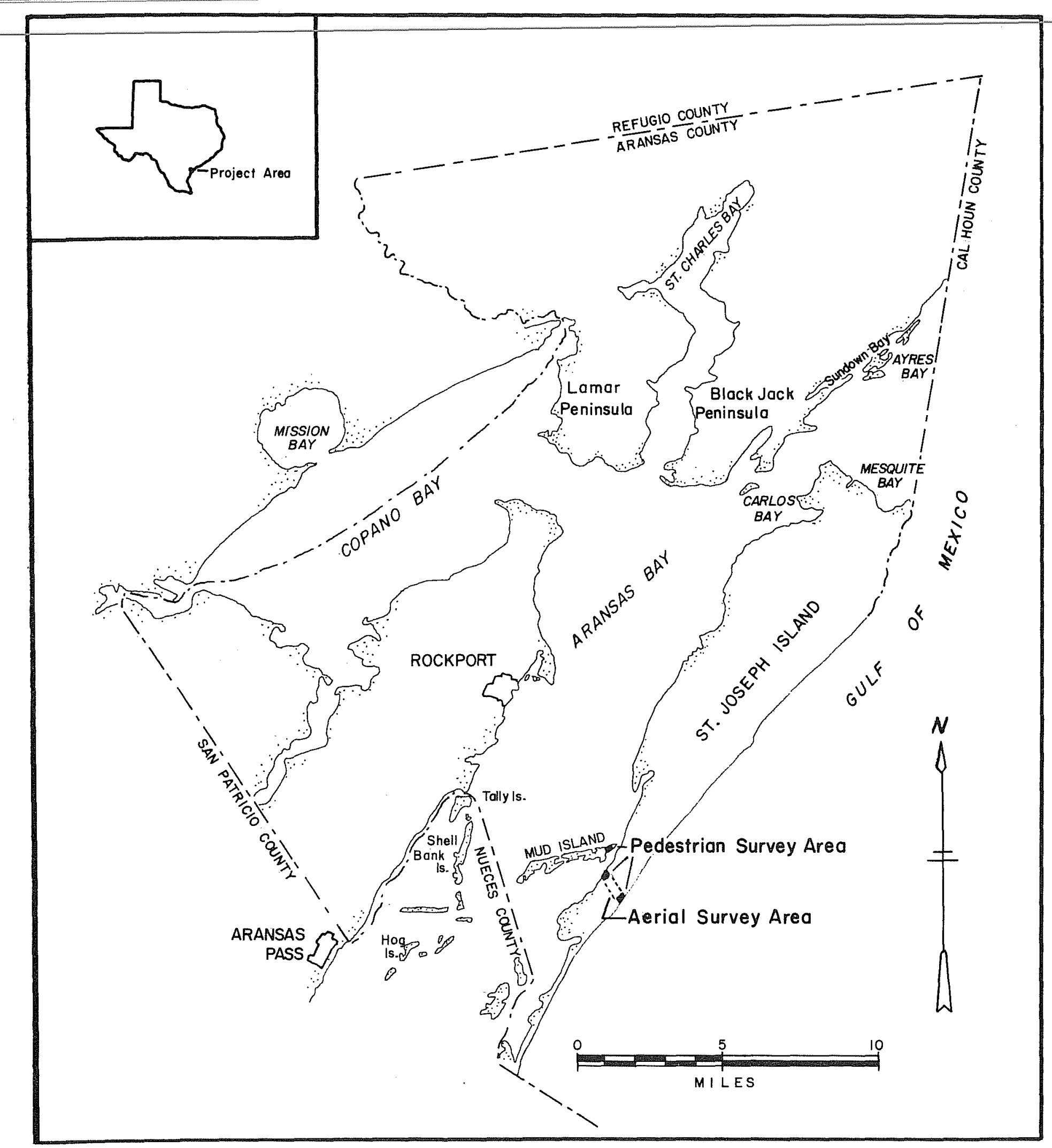

Figure 1. Mud Island/St. Joseph Island Survey Area. Shown are the areas of pedestrian and aerial surveys. 
Archaeologically, St. Joseph and Mud Islands fall within the middle of the central Texas coastal division, the area between the Brazos River and Corpus Christi, with the southern coastal division being from Corpus Christi to the mouth of the Rio Grande (Campbe11 1958:146). Hester (1975a:Map 1) cal1s these the Rockport and Brownsville complexes. Recently Patterson (1980:104) has summarized the archaeology of the upper Texas Coast, covering the area from the Brazos to the Sabine Rivers.

Physiographically, the area is in the Coastal Lowlands of the West Gulf Coastal Plains (Fenneman 1938) and within the Texan Biotic Province (Blair 1950).

PREVIOUS ARCHAEOLOGY OF THE AREA

Prehistoric Period

Campbell (1958b) summarized the archaeological work in the central coastal area up to the time of publication. He has reported several sites in the central coastal area (Campbell 1947, the Johnson site [type site of the Aransas Focus]; Campbe11 1952, the Kent-Crane she11 midden; and Campbe11 1958a, Live Oak Point). A bibliographic guide to the archaeology of the area can be found in Hester 1974.

Martin and Potter (n.d.) made the only comprehensive survey of Aransas, Copano, and St. Charles Bays during 1927, 1928, and 1929. They reported 92 sites (ibid.). They commented frequently on the rapid disappearance of sites that had been present only a few years before, and predicted that they would all be destroyed in another generation if steps were not taken immediately to scientifically investigate and protect them. From map studies alone, it is readily apparent that most of their sites have already been destroyed by real estate development, bridge building, highway development, oil field activities, plus the influx of thousands of people, and several massive hurricanes.

Martin and Potter (n.d.) did not report sites on St. Joseph Island, but they do make a reference that is pertinent to the present survey. They (ibid.:2) describe Goose Island, their site no. 15, as the beginning of a series of islands and submerged reefs that were known by people still living then to have been used by bands of from 30 to 50 Karankawas to cross nine miles of Aransas Bay single file to St. Joseph Island. Newcomb (1967:60) also states that one of the Karankawa bands, the Copanos, Tived along Copano Bay and on St. Joseph Island. Cabeza de Vaca (Hodge 1907) found Karankawa on St. Joseph Island.

Corbin (1974) has constructed a model of cultural succession for the Central Coastal area, based on seriation and matrix analysis of artifactual materials from the few excavated sites in the area. Story (1968) has produced the only radiocarbon dates so far in the area from $41 \mathrm{SP} 43$ on the southern end of the Live Dak Peninsula. This probably establishes the end of the Archaic period at ca. A.D. 1200.

Only a few sites are recorded from the barrier islands adjacent to St. Joseph Island, none of which have been excavated. Four sites have been recorded from Mustang Island to the south (Texas Archeological Research Laboratory [TARL] files, Austin) and, according to Hester's (1975b) findings in a re-survey of the 
area, these recordings were of questionable reliability. Hester (ibid.) at the same time looked at the southern tip of St. Joseph Island and found nothing.

The TARL files indicate three sites registered for Matagorda Island to the north all clustered about the northern tip of the island. None have been tested. Flint scatters, she11 ornaments, and pottery sherds apparently comprise the inventory of these sites. No sites have been found on the Gulf site of Matagorda Island. No sites have ever been recorded in the TARL files for St. Joseph Island.

\section{Historic Period}

European contact with the Karankawa first occurred in 1528 with the shipwreck of the Narvaez Expedition. Cabeza de Vaca not only survived the experience, but is also responsible for most of what we know ethnographically about the Karankawa (Hodge 1907). For 150 years after Cabeza de Vaca until La Salle accidentally landed at Matagorda Bay and established Fort St. Louis in 1685, no Europeans were present. The Spanish sent an expedition to destroy the fort in 1690 only to find that the Karankawa had massacred a 11 but five of the colonists. Thereafter, the Spanish, the French, and finaliy, the Texans decimated the Karankawa population, with the last Karankawa disappearing sometime in the 19th century. Martin and Potter (n.d.) describe "tipi circles" which they attribute to the Karankawa, and they interviewed a number of older people who had seen living Karankawa. Newcomb (1961) gives good descriptions of the Karankawa and their lifeways.

\section{MUD ISLAND SURVEY}

\section{Procedure}

The survey party flew from Aransas County Airport to Mud Island, located the survey markers for the proposed pipeline, and photographed the route from the helicopter. A landing was effected on the northwestern side of the island at coordinates $2,648,487.84^{\prime} \mathrm{E} / 47,464.39^{\prime} \mathrm{N}^{*}$ (Fig. 1). Line-abreast transects 50-meters apart were walked until 150 meters were covered either side of the centerline, which terminated on the southeastern side at 2,646,586.22'E/ $47,179.85^{\prime} \mathrm{N}$. Shell is highly visible on both shores, and ground visibility was good in the interior despite marsh grass cover. A wide variety of she11 was observed, with oyster being predominant. The island, which is approximately 350 meters wide at this point, appears to have been frequently inundated.

Results

Nothing of historic or prehistoric archaeological interest was found. There are no elevated points or natural barriers on this very flat mud and shell

*Coordinates from USGS A17yns Bight, Texas 7.5' Topographic Sheet expressed in feet, Texas Coordinate System, south centra1, to match Channel Industries physical survey. The survey measurements however are in standard metric measurements. 
island, so it is doubtful that any man-made artifacts could long survive the natural elements at work in Aransas Bay. It must also be pointed out that this is only a very smal1 survey area, 300 by 350 meters, and can not be considered an adequate sample for the whole island.

\section{Conclusions}

The construction of a pipeline across the surveyed area will have no impact on historical or archaeological resources.

ST. JOSEPH ISLAND SURVEY

\section{Procedure}

Survey markers were located from the air, and the route from 2,646,032.13' $\mathrm{E} /$ $42,186.02^{\prime} \mathrm{N}$ to $2,648,801.97^{\prime} \mathrm{E} / 38,196.32^{\prime} \mathrm{N}$ (see Fig. 1) wa.s flown at approximately 50 feet in altitude. The interior portion of the area was covered by dense marsh grass, with poor ground visibility. Only coyotes and jackrabbits were observed, and it was determined that walking transects across the interior would be fruitless. A landing was effected at the southeastern or Gulf coast end, where there are wide sandy beaches and sand dunes rising to approximately 10 meters above the beaches. An area 200 meters either side of the centerline and 300 meters into the interior was thoroughly covered by a random search pattern. The survey team then flew to the northwestern or Aransas Bay terminal, where there are no sand beaches and the sand dunes are less frequent than on the Gulf side. A random search pattern was again utilized over a 300 by 400 meter area.

\section{Results}

There should have been a high probability of finding archaeological traces, as Martin and Potter (n.d.), Newcomb (1961), Cabeza de Vaca (in Hodge 1907b), and others place the Karankawa on St. Joseph Island in historic times. The Gulf side of the island was littered from waterline to 200 meters or more inshore with washed-up modern artifacts and asphaltum concretions. Nothing of historical or archaeological interest was found.

\section{Conclusions}

The construction of the proposed pipeline across St. Joseph Island will have no adverse impact on historical or archaeological resources.

\section{Recommendations}

St. Joseph Island is potentially the last chance for finding undisturbed rema ins of the Karankawa and their predecessors in the central coastal archaeological area. Any future $0 i 1$ or developmental activities there should be closely monitored. 
Blair, W. F.

1950 The Biotic Provinces of Texas. Texas Journal of Science 2(1):93-117. Campbe11, T. N.

1947 The Johnson Site: Type Site of the Aransas Focus of the Texas Coast. Bulletin of the Texas Archeological and Paleontological Society 18:40-75.

1952 The Kent-Crane Site: A Shell Midden on the Texas Coast. Bulletin of the Texas Archeologieal and Paleontological Society 23:39-77.

1958a Archeological Remains from the Live Oak Point Site, Aransas County, Texas. Texas Journal of Science 10(4):423-442.

1958b Archeology of the Central and Southern Sections of the Texas Coast. Bulletin of the Texas Archeological Society 29:145-171.

Corbin, J. E.

1974 A Model for Cultural Succession for the Coastal Bend Area of Texas. Bulletin of the Texas Archeological Society 45:29-54.

Fenneman, N. M.

1938 Physiography of Eastern United States. McGraw-Hi11, New York.

Gagliano, S. M.

1977 Cultural Resources Evaluation of the Northern Gulf of Mexico Continental Shelf. Cultural Resource Management Studies, Interagency Archaeological Services, Washington, D.C.

Gatschet, A. S.

1891 The Karankawa Indians, The Coast People of Texas. Archaeological and Ethnological Papers of the Peabody Museum, Harvard University $1(2)$.

Hester, T. R.

1974 A Bibliographic Guide to the Archaeology of Southern Texas. Journal of South Texas 1 .

1975a Some Aspects of Late Prehistoric and Protohistoric Archaeology in Southerr. Texas. Center for Archaeological Research. The University of Texas at San Antonio, Special Report 1. 
Hester, T. R. (continued)

1975b Evaluation of Archaeological Resources in the Area of the Proposed
Prime Project to prepared for the Southwest Research Institute. Channel. Report

Hodge, F. W., editor

1907 The Narrative of ATvar Nuñuz Cabeza de Vaca. In, Spanish Explorers Newcomb, W. W., Jr.

1961 The Indians of Texas. University of Texas Press, Austin. Patterson, L. W.

1979 A Review of the Prehistory of the Upper Texas Coast. Bulletin Story, D. A.

1968 Archeological Investigations at Two Central Texas Gulf Coast Sites. State Building Commission, Archeological Report 13.

Valastro, S., Jr., E. M. Davis. and A. G. Varela

1978 Radiocarbon Dates XII. In, Radiocarbon 20(2). 


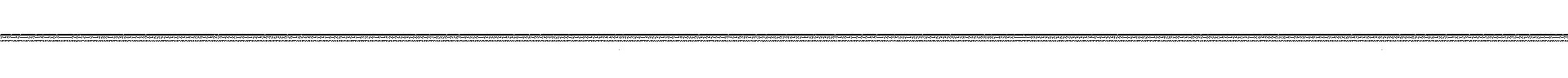

